\title{
Article
}

\section{CLINICAL LIFE IN THE CONTEXT OF THE PANDEMIC}

\author{
Adrienne Harris ${ }^{1}$, Veronica Csillag ${ }^{2}$, Naomi Cutner ${ }^{3}$, \\ Nancy Freeman-Carroll ${ }^{4}$, Sarah Jo Mayson ${ }^{5}$ and \\ Marilina Rufino ${ }^{6}$
}

In this article, six analysts describe theory and practice in the time of COVID-19, examining the quality of après-coup in the way that the pandemic and its attendant crises trigger early memory and early experiences of helplessness. In the clinical events we see that the age of the patient, the circumstances and approach of the analyst, the novelty of the frame are all crucial determinants of clinical outcomes.

KEY WORDS: après-coup; developmental level; frame; helplessness https://doi.org/10.1057/s11231-021-09308-9

Adrienne Harris, Ph.D., Faculty and supervisor, New York University Postdoctoral Program in Psychotherapy and Psychoanalysis; faculty and supervisor, Psychoanalytic Institute of Northern California: Co-director, Sándor Ferenczi Center, New School, NYC.

Veronica Csillag, LCSW, Past co-director, faculty member, training and supervising analyst, Manhattan Institute for Psychoanalysis. Associate Editor, Psychoanalytic Dialogues.

Naomi Cutner, LCSW, Supervisor, Director of Institute's Clinic, Manhattan Institute for Psychoanalysis.

Nancy Freeman-Carroll, PsyD., Supervising analyst and faculty member, William Alanson White Institute, NYC.

Sarah Jo Mayson, Ph.D., clinical psychologist in private practice, clinical supervisor, Pace University, psychoanalytic candidate, New York University Postdoctoral Program in Psychotherapy and Psychoanalysis.

Marilina Rufino, Ph.D., Spanish-English bilingual clinical psychologist, in private practice, psychoanalytic candidate, New York University Postdoctoral Program in Psychotherapy and Psychoanalysis.

Address correspondence to: Adrienne Harris Ph. D., 80 University Place, 5th floor, New York, NY 10003. Email: adrienneeharris@gmail.com. 


\section{INTRODUCTION}

\section{Adrienne Harris}

In this collaborative essay, we address, through different clinical examples, the unique and daunting experiences of psychoanalytic work in the time of the present pandemic. Between our first sensitivity to the unfolding spread of COVID-19 to the current social crisis around race relations and racial violence, a lot has happened. We have in the United States become subject to a sequence of transformations which are both terrifying and dangerous AND hold the possibility of growth and new forms of social consciousness.

In the clinical domain, we are finding that there are a number of common issues and then also striking differences in our experiences. This is a situation of shared trauma. Work, daily life, social and political circumstances have general, as well as specific, effects. Using Joseph Dodds' (2011, 2020) model we conjure up the Three Ecologies: natural, social, and mental and see that therapeutic work is situated within these three interlocking situations, or 'assemblies' as Guattari (1989) termed them. Following Dodds, we can take up another metaphor that Guattari elaborated. Thinking of our situations as a rhizome, we can imagine complex nonlinear dynamics, fractals, and assemblies in which the political, the social, and the mental interweave in unique, often unpredictable, emergent forms.

Using the concept or formation rhizome offers us some mobile, vitalizing and complex ways to see our clinical situation. At an anatomical level, the rhizome is a structure that travels horizontally and emerges in novel and unpredictable situations to grow. The rhizome is set as a creative metaphoric alternative to the arboreal structure: a tree emerging from a root and flowering, a structure controlled from one origin point. Thinking through the features of the rhizome we have much unpredictable potential. Circumstances which could be social, political, environmental and natural, unconscious and conscious all participate in individual and collective experience.

So, we offer clinical work, being attentive to the generic and the particular, to shared trauma and distinct reactivity. Particularly in the clinical setting, I have been thinking of COVID-19 as an experience of après-coup (Harris, 2020). It is a trauma in its own right. But also, it is a moment, an experience in the present that opens all the unmetabolized, untranslatables that any of us, all of us, have had to contain, rework, and keep at bay over a lifetime.

Looking through the lens of trauma theory and the work of Freud, Lacan, Laplanche and others, I want to make use of the concept of après-coup, variously translated as nachträglichkeit or afterwards-ness. I draw on 
Laplanche's model $(1997,1999,2015)$ to stress the power of the messages from others, another, alterity in the formation of sexual/gendered subjectivities.

It is important to see that often these triggers in the present-this aprèscoup - often involve not only the interpersonal but the state. As many are pointing out, the pandemic is also an encounter with the imperatives of the state. Nancy identifies this process. "The contagious brutality of the virus spreads as administrative brutality." Later in the same essay he notes "The viral magnifying glass enlarges the characteristics of our contradictions and of our limitations. It is a reality principle that collides with the pleasure principle. Death is its companion ..." (Nancy, 2020, p. 45). A patient finds herself remembering being tear gassed by police as a young teenager in the country she had grown up in and left as a young adult. In a long treatment, this memory had never surfaced.

Here I also want to introduce Faimberg's original conception of aprèscoup, in which we see the retrospective and anticipatory movement of time:

Lacan was the first to highlight that form of Freudian dialectical temporality known as Nachträglichkeit. Part of my own contribution has been to link psychic change to Nachträglichkeit, including a broader concept of it (Faimberg, 2007a). I have presented the hypothesis that Winnicott's "Fear of Breakdown" (1974) can be seen as a particular form of temporalization, the operation of Nachträglichkeit (Faimberg, 1998) [....] As we know, Winnicott says that the breakdown the patient fears and expects to come in the future has actually already taken place at a time when there was, properly speaking, no subject to experience it. In a nutshell, my reasoning has been the following: Winnicott, in the Freudian tradition, gives central importance to the concept of Hilflosigkeit: the child's helplessness due to prematurity (a characteristic of human beings), a key concept. His concept of primitive agony is linked to the associated sense of the child's helplessness (Faimberg, 2013, p. 853).

I also link these moments of après-coup to a crucial and universal early experience, the inaugurating of subjectivity in initial conditions of helplessness. In the three months of working remotely and the increasing deepening of collective understanding of the meaning and impact and scope of the 'pandemic', I have been struck by the resonance of early and deep experiences of terror, of helplessness but idiosyncratic for each individual. We have Winnicott $(1959,1963)$ to thank for the deep understanding of how helplessness lies at the very inauguration and unfolding of subjectivity.

An extraordinarily astute account of this experience, implicating the trauma of the pandemic and its provocative activation of a series of other, 
highly particular traumas within one family was the subject of Amy Herzog's (May 20, 2020) essay in The New York Times Magazine. She tracks the re-traumatizations within two generations of core disruptions and traumatic separations as they are both activated and processed. The author invents a wonderful Winnicottian game of pretend, upending rules and generations in order to find space to express terror and shame. One element in the narrative that seems particularly important is that the game and the play and the narratives and experiences that enfold the family in the madeup game "Sisters" explores AND transforms shame. Often our most difficult and dysregulating affect, in this process, a family is guided, interestingly by a child psychologist mother and the guiding spirit of Winnicott himself-in the form of a book that unites the family in time and space.

Someone with a history of displacement, of removal from an abusive parent and the subsequent turmoil of foster care placements, feels the danger of fracture to her family, displacement of her children, the overturning and threat to her hard-won stability and achievements. In the course of therapy, she had come to a sturdy secure life, functioning as a parent, and developing a professional competence. She and I were both surprised at the intensity with which she experienced deep helplessness and ominous consequences, particularly for one of her children, the child she is most identified with. She found herself consumed with the danger of fracture to her family, displacement of her children. In an instant, everything could be lost. True in the moment, but also deeply a repetition of her history, a history she has worked hard to metabolize.

The clinical vignettes and case material range widely over different analytic pairs and distinct developmental and characterological situations. There is for all the experience of a partially shared and also distinct encounter with trauma. We reflect on the impact of frame change, often even in one analytic couple this ranges between more and less intimacy. We have had to attend to the impact of intense and often quite unexpected countertransference: irritability, altered states, feelings of new freedom and of coercive conditions, including the shared/distinct experiences of quarantine.

We have put the clinical portions of this essay in a particular order, following work with people across the life span, starting with work with children by an analyst living with her child, moving through two clinical accounts of work with a young adult, thrown back into his childhood home, working with an adult with whom he is building a complex and deep transference. We conclude with two accounts of work with older people, facing the joint challenges of isolation and aging. One from an analyst who is in a younger age group and one who is in the same age range as her patient. In this way, we are privileging developmental situations, among 
other matters of gender, caste, and culture to give a rich picture of the cultural, social and psychic forces at work at this moment.

\section{THE CORONA GHOST}

\section{Marilina Rufino}

During COVID-19 I continued working with the children I had been seeing in my private practice. The therapeutic frame was altered and keeping the parameters of the frame with the new confinement limitations became somewhat "subversive." In supervision and group psychoanalytic discussions, the idea of "maintaining the frame" despite the virtual component persisted as a shared understanding. A shared traumatic experience had affected us all, our subjectivities and idiosyncrasies were re-signified via a return to a state of an early and somewhat once known vulnerability. An après-coup, retroactively re-signifying what was already there; a kind of catapult effect of being pulled back and then quickly pushed back into the here and now.

Yet at the same time, the question remained; how to honor the therapeutic frame in my work with children and adults, but particularly with children where play is the stage of the analytic work. Within these dynamics, my multiple roles as a therapist, a mother, and woman had to learn to co-live, cohabitate in a constrained space during quarantine. The challenges of being a mother and seeing children during COVID-19 were augmented. Given how our work and personal lives had merged out of the need for confinement, my mind learnt to swiftly switch from my role of a therapist to my role as a mother, and often becoming the school teacher for my daughter. These transitions were conflictive and charged with visceral emotions. Learning to transition swiftly into these different roles was far from easy. These internal and personal conflicts gave me important insights into the family dynamics of the children I have been working with, understanding how each family needed to co-create their own school and work schedule, while hoping for positive results.

What has been significant support during these times is the gratification I find in working with children, as a co-creation of mature shared space for co-regulation and co-creation of meaning more so than the work with adults, where there is less of an asymmetry in terms of age and development. In other words, I find immense pleasure in how much I learn from the work I do with children. Similarly, in my role and development as a mother, I continue to learn from my daughter, who has given me a unique 
experience via her poetry writing and behavior at home to observe unconscious fantasies at play during COVID-19.

\section{Corona Ghost}

Whoosh the sound of the wind

You never know if it's a ghost or a witch

It goes through NYC to California and around the world

But you don't know where it is right now

It might be behind you, you don't know

This is all I need to tell you but be aware it is there

-Poem written by my 9-year-old daughter 5/7/2020

Her "Corona Ghost" poem was short and simple, though to the point, "We don't know if it's here or there...it's everywhere...be (a)ware." Children were cut off from the most essential component in learning, the social—and the meeting of minds and bodies. Learning shifted abruptly, and the overadaptation was to some degree, inevitable. So, how was I able to carry over the therapeutic frame? I relied on my clinical training through observation and the concept of "here and now." Zoom became the vehicle by which the virtual sessions took place and I admit that I went into the first sessions with children with certain skepticism. When the quarantine began, I had been seeing two 9-year-old boys in third grade for a year, the same age as my daughter. In retrospect, this coincidence was far from random. Although the boys initial presenting problems were different from that of my daughter's, their similar developmental stage helped me understand an internal and unique perspective on how to mentalize their most unconscious, nonverbalized fantasies and fears.

Both boys were brought into treatment by their mothers, due to social inhibitions and difficulties regulating their emotions, particularly at home. What was palpable in my experience with both boys during COVID-19, was their interest in continuing working with me despite the limitations of the therapeutic frame. The boys were both skillful in learning about the new online platform, and in connecting with me via the screen. I learned much from their abilities and display of interests, as often happens during inperson analytic work with children. The novelty of the Zoom experience gave both boys the opportunity to "show off," or better said, to show me how they have learned to master the multiple functions of the online application. They both suggested using the "whiteboard" to draw together, a kind of more simple play such as tracing lines on a paper. Tic Tac Toe and Hangman (guessing the letters to unveil the word) became their favorites games. Of special interest was how these boys both discovered the function of the "Waiting Room," who only the Host of a Zoom meeting has access. 
A month into COVID-19 confinement, they shared their experiences of being put in the Zoom waiting room and they wanted to know how the experience of being in the waiting room was for the host. In my mind the phrase "waiting room" was quickly associated with the waiting room of the consulting room; as well as the experience of waiting for our lives to resume was like waiting in a black screen display (the Zoom waiting room screen display.) A sort of eerie shared feeling, of not knowing what we were waiting for. Simultaneously, and as way of coping with reality, co-creating meaning from our shared traumatic experience via a regulated rhythmicity, of becoming interested in the Other. Coincidentally, both boys asked me if they could be the Host so they could experience the virtual waiting room not as a guest but as the one in control of letting the other participants in and out of the waiting room. The process of co-creating a shared and a safe learning space was unfolding. One of the boys asked me via his mother if he could set up the meeting, so his mother sent me the Zoom meeting number and password. His satisfaction in experiencing being the one in control of our meeting was profound. The game had begun! I was often put in the waiting room and invited back again. Both boys started to show me their work, from a short presentation on Pokémon Powers to their personal drawings. The symbolic function of role playing and taking turns, in this context, had given them the make-believe experience of being in control and in charge, during a time when vulnerability to a state of dependence and uncertainty is being felt as a collective trauma.

Although the pandemic has been experienced as sinister and invisible, it was also later experienced as somewhat familiar after being quarantined for two months. The social unrest that violently unfolded, after the homicide of George Floyd speaks to the interconnectedness of the three ecologies suggested by Guattari (1989), adding to the current reality a different kind of fear and anger; but at the same time, it added a loud, and much needed, "cry for help." The homicide of George Floyd was a social and political expression of the underlying and persistent oppression of our most vulnerable. Somewhat contrary to the experience of COVID-19, this was experienced as visibly bloody, violent, and unsettling. The civil unrest became a humanizing response to give voice to the less empowered and neglected part of the socio-political forces; it unveiled the underlying reality of a violent disparity of wealth and the increasingly limited resources for the more marginalized and neglected citizens of our society. As my daughter reminded me in her poetry during the uprising the week after George Floyd's homicide on May 25th, 2020: 


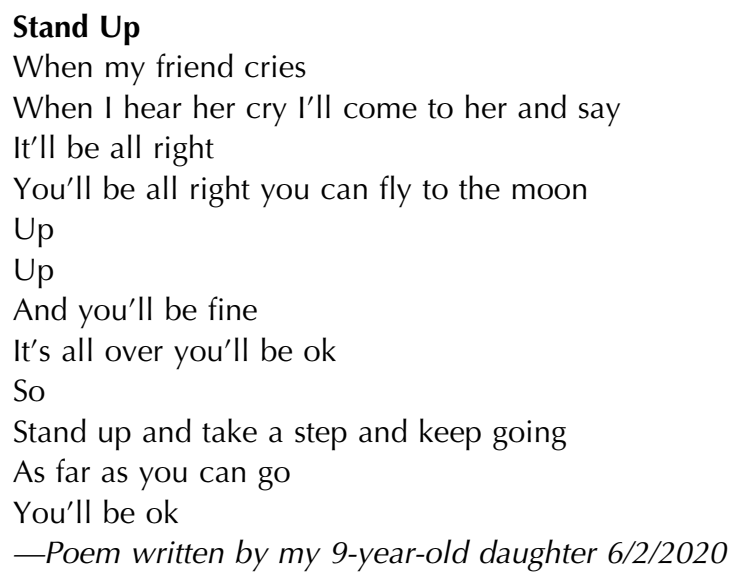

Four months into the quarantine, the new normal was far from normalcy. My work with children and my role as a divorced mother during COVID-19 have become the new frontier. We have all been put into this gigantic and abysmal "waiting room," uncertain of what we are waiting for. But what has become apparent to me is a sort of the steady hunger for connection and new meanings, while creating new ways of relating and engaging. Life and death instincts have been called upon our existence once again in a radical way. I found myself returning to the teachers and mentors who started this process and way of thinking that that we call psychoanalysis, and they, too, persevered through new frontiers. Let's keep playing; children are a constant reminder of what is often needed to survive during times of despair: love.

\section{TENDER TEARS}

\section{Veronica Csillag}

Enrique is a 25-year-old man of Mexican descent. He has olive skin and jetblack hair. He reads Spanish and identifies himself as Latino. His parents are immigrants, they have not finished high school and have blue-collar jobs. Money has always been tight. His parents' command of English is limited. Immigrants, even those with higher education and especially those without, tend to lose status when they land here. There is disorientation, struggles with the new language and culture. Professional paths are blocked. As a child Enrique was quickly parentified: frequently he was cast as translator and custodian to his parents. 
Enrique grew up in rural Pennsylvania in a mostly white enclave. He attended public schools where he was bullied a lot. First, because he spoke no English (the family only spoke Spanish in the house), then because he was ethnic, and then because he was angry. As a testimony to his innate intelligence and his determination, he finished high school as a valedictorian and was accepted to the University of Pennsylvania among other elite colleges. Sad to say, many of his classmates and even some of his teachers implied that he only got in because of affirmative action. He chose UPENN because of its prestige but also, I suspect, because it was closer to home than the other top schools offering him admission. Among his areas of angst, separation anxiety is high on the list. Personally, and inter-generationally, he had to endure so much loss and so many other changes: country, language, culture, extended family, fluctuating social status.

The years at UPENN were supposed to be his victory march but proved to be yet another experience of humiliation. While the bullying evolved and became more sophisticated over time, it did not stop. He was shamed at frat parties for his lack of worldly polish, he was rejected by some of the "cool/ hot girls." He did not fit in with the mostly rich, white, preppy culture.

He graduated college with an impressive GPA, got a promising job in advertising, and moved to New York City. He came to see me a year or so later, seeking help with a complicated and volatile mix of anxiety, insecurity, and uncontrollable rage, thinly plastered over much guilt and shame. It is well established that downward social mobility exerts a toll but there is a high price to be paid for upward mobility as well. There are obvious advantages, such as higher status and financial advancement but there is also much pain. There is anxiety, alienation, confusion, often accompanied by somatic syndromes. Enrique has significant gastrointestinal as well as joint problems in spite of his youth. Adjustment to a new socioeconomic class will inevitably result in varying degrees of estrangement from one's family of origin. Enrique has an Ivy League education, he is fully bilingual, and also speaks a couple of other languages, Italian and Japanese among them, whereas his parents barely mastered English and often struggle with paying their bills. Enrique is caught between the sophisticated world of New York City's young professionals, where he believes himself to be too crude and too "macho" to be accepted and the less accomplished, more conservative, and in many ways politically incorrect circles of his hometown, where he does not really belong anymore either. A case in point: The other day, back home, he was helping a friend move and talked to me from his father's truck. He said: "Around here only white people rent U-hauls, let alone hire a moving company, everyone else owns a pick-up truck or knows someone who owns one." In his milieu and especially in his personal experience, class, race, and immigration status intersect. 
Understandably, Enrique has a tremendous amount of class and racial resentment. He tends to assume that every white professional in New York City, myself included, is a racist, upper-class devotee of capitalism. Even though this is far from the case he has a point: white professionals all participate and benefit from a society built on racial and economic oppression and exploitation. He is also somewhat of a self-described misogynist. He hates women for all the rejection he experienced. He imagines that every good-looking, accomplished young woman has a field day in the realm of dating. They can have any guy they want, and they are reveling in their power and gratification. Any "girl" who has had more sexual partners than he has is a "slut." Sometimes he defends his views, sometimes he recognizes that they are unfair generalizations.

In the transference I have been constructed to represent this evil world of privilege, a white, neoliberal, pseudo-progressive feminist, and possibly also some version of the exciting but rejecting object, the unattainable hot and cool woman. Every time I respond to his political diatribes, he contemptuously dismisses my comments. Working with him can sometimes feel like being in a battlefield. While I find his hostility wearing and intimidating, I have a lot of compassion and respect for him. Despite all his attempts to cast me as the spoiled white woman and use me as a bad object, I am also aware of the tremendous suffering he has experienced. Still, he tends to reject my empathy and admiration: they make him feel vulnerable and emasculated. I struggle with this bind in the treatment. I need to titrate my empathy: too much will elicit his condescension; too little will only fortify the bulwark of his defenses. While I am aware of this dynamic, the moment-to-moment process is not fully conscious: I adjust my words and the tone of my voice according to what is coming from him, whether it is anxiety and distress or unfriendly scorn; whether I feel like we have a good flow or I find that I have a knot in my stomach and I am afraid that I will be demoted or dismissed.

Somewhat of a hypochondriac to begin with, when the coronavirus reached New York, Enrique left town with the first cohort. He moved back to his parents' house in Pennsylvania. At first, he wanted to suspend treatment but when I suggested that the pandemic and its restrictions might continue indefinitely, he agreed to continue virtually, mostly just to keep the "local economy" (i.e., me) financially solvent. I was taken aback but hardly surprised by the barely concealed contempt. He was just giving me a taste of what he had to endure.

The first few tele-sessions were difficult. He tends to speak too fast and anxiously slur his words, possibly in an attempt to dissociate from his own earned privilege. With poor electronic "connectivity" added to the mix, frequently, I had to strain to hear and understand him. His social anger 
intensified and was now complemented by genuine concern about his employment prospects and his economic survival.

Then approximately a month into the lockdown a remarkable development occurred. After wandering around the house and wondering what might be the most appropriate corner from which to talk with me, he settled on - and in-a small room, full of stuffed animals of various sizes. Dozens of them. When I inquired about these creatures, he was reluctant to respond. While he allowed me to see him in this space, he appeared to disavow its presence. Eventually, he disclosed that the room used to belong to his mother. She would collect plush toys and she still does. This was his new office. What an incongruent environment for an angry, young, "macho" Latino! And then he started to discuss his reluctance to talk frequently with his girlfriend, who was staying with a relative in Maryland, his difficulty with giving compliments and even with telling her that he liked (never mind loved!) her.

"I appreciate her as a friend and as a lover but I don't have this fluttering in my heart when I see her, I don't want to hug or kiss her if it is not about sex. Shouldn't I have more feelings for her, after over a year? I don't know if I love her, shouldn't I by now? How will I know?"

"You don't feel that kind of overflowing emotion."

"Not really."

"Have you ever? Like you want to hold someone tight and tell them you love them?"

"I don't think so."

"One needs to allow oneself to be open and vulnerable to love someone...but you are afraid of that...given your history you don't want to risk getting hurt, rejected. You are cloaked in your angry, judgmental armor... You don't know what you are missing." Even as I was uttering these words, I was becoming aware that I was drifting onto dangerous terrain, directly eliciting his vulnerability. This was an enactment: in reaction to his rigid defenses I crudely reached after the softer core. He would have none of it.

"I DO know. That's why I am here. That's what I have you for...I do not choose to be as contentious and provocative as I often am, but I can't help it. I've been hoping that one day you will convince me that not all sexy women are sluts but so far you have not said anything that would be particularly persuasive."

For a moment Enrique showed some skin, revealed a bit of the underbelly only to immediately transition to righteous indignation: Don't tell me what I already know, I know what I am missing, and it is YOUR job to fix it, but 
you haven't, I have to wonder if you even know what you are doing. Obviously, this is my experience and not his words. Still, even with the defensive cover-up, Enrique has begun to allow me to see a softer, more vulnerable part of his self. Bion $(1957,1962)$ would call that the nonpsychotic part of the personality, willing to see reality, without evasion or evacuation. Thinking along similar lines, Rosenfeld (1971) talks about the narcissistically injured subject's need to relinquish their alignment with their omnipotent and destructive phantasy of triumphant self-sufficiency and connect to their more humble but saner, dependent core (p. 175).

I believe I had a role in this shift in some ways, mostly by my survival, without much retaliation and certainly without abandonment, of his hostile attacks (Ogden, 2016; Winnicott, 1969), and also by my compassionate attitude and especially, by my willingness to rein in my empathy whenever it was unwelcome. What may have also contributed to this change is my tendency to privilege what Ogden (2019) refers to as ontological as opposed to epistemological psychoanalysis. My focus is more on how to be in the world, how to live, how to immerse in an experience, how to play. Ogden builds mostly on Bion and Winnicott, both of whom are dear and near to my psychoanalytic heart, in belaboring his ontological perspective and his dedication to "allowing the patient the experience of creatively discovering meaning for himself, and in that state of being, becoming more fully alive" (Ogden, 2019, p. 661). Enrique realizes that I care about him and he appreciates that I am willing to bend the rules of the psychoanalytic workbook, classical and subsequent, in order to find him, even if mostly in opposition. In the process of being found a genuine desire to change and become a less combative and more affectionate person has emerged.

I have shared a lot of myself with Enrique, much more than I typically do. I told him a bit about my own background, he knows that I am an immigrant. I implied that I had my own share of challenges with money as well as acculturation. I often engage with him over politics-while my psychoanalytic superego is sternly wagging a finger at me. I frequently agree with his radical views, but he prefers to zoom (!) in on our differences. Polemical exchanges are not typically considered psychoanalytic discourse, paradoxically though, our talks about socio-political matters enriched the context of the transference-countertransference matrix and facilitated the deconstruction of his view regarding my analyst self, initially all-too easily assembled as just some spoiled bougie white lady. With some genuine tender trust having developed between us, he is now in search of the elusive good-enough object he can finally love.

Still, I believe that other environmental and incidental factors also had a great, cumulative impact. Seligman (2014) likens the analytic situation to a nonlinear dynamic system, in which small, unpredictable changes can lead 
to a tipping point and ultimately result in a dramatic shift. When the above dialogue took place, Enrique was back with his family where there is no doubt about his accomplishments, and he does not need to convince anyone of his value. In this habitat life does not have to be daily combat. Surrounded by soft, fluffy animals, symbols of love and affection, eating his mother's meals, he is finally allowing himself a good feed.

This process is ongoing. Some weeks after Enrique complained about not being in touch with delicate feelings his uncle died somewhat unexpectedly. He was in his 40s. He had been ill but was supposed to last much longer. Enrique was overwhelmed by guilt for not having spent more time with him. He was feeling really bad for his uncle's 10-year-old son and teenage daughter. Shortly thereafter he finally had a few days with his girlfriend. Then she left for Korea, where she is originally from. She would not be returning for at least six months. In the session following her departure Enrique disclosed that he had cried after she left. He cried for the first time in a very long while. Then he added that he felt empty and aimless and that he did not know what to do with his life. He also complained about having to work out, whereas "others" are naturally fit and toned.

"I hate working out," he said. "Will I have to work out for two hours each day for the rest of my life if I don't want to be a fat piece of shit?"

"Did you really have to call yourself a 'fat piece of shit'?" I responded. "I guess you had to. So harsh. You are so hard on yourself."

Enrique is full of despair. He is mourning his losses without being able to properly grieve, given the coronavirus-induced implosion of time and space. While his masochistic self-flagellation is defensive, he is no longer hiding his pain.

The coronavirus killed thousands and devastated millions. It intensified paranoiac anguish, solidified dysfunctional defenses, mostly manic denial, in many more. It seems that for Enrique the opposite happened: it opened the door to psychic growth. In this strangest and scariest situation, communicating via video, the transference-countertransference relationship shifted. We both became more visibly vulnerable. I would not hide my anxiety and despair and we both became more mellow, more simply human than otherwise (Sullivan, 1940, p. 16). This matrix helped Enrique partially dismantle his defensive armor and open himself up to experiencing longing and tenderness.

\section{Postscript}

I showed the manuscript to Enrique before submitting it to this journal. I was nervous. I was afraid that he would object to my description of his tender 
side or to have attributed the emerging affection between him and the important people in his life, including me, to our work. It did not turn out to be the case. True to himself, he made a couple of derogatory remarks about content and style, but other than that he accepted the paper as it was, more or less recognizing himself in his portrait. He chuckled a few times as he was reading and was particularly pleased that he had kept me on my toes: he took pride in having managed to intimidate me.

Since that time, our relationship has further deepened. The dialogue is less contentious, the mood more somber. There is tacit acknowledgement that we are more comrades than enemies, more or less on the same side of the barricade in this Mad Max universe. Knowing that he knows that I know that he has a beating heart in his chest helped us both relax a bit. I, for one, am less cautious about showing empathy: he is more willing to accept the holding and I no longer feel the need to defensively collude with the antilibidinal denial of need and desire.

\section{COVID-19: A CHALLENGE OF RELINQUISHING THE DEAD MOTHER}

\section{Sarah Jo Mayson}

When first reflecting on my experience of the COVID-19 pandemic, my thinking was murky and confused, short-circuiting my capacities for documentation. Scholars and bloggers delivered eloquent formulations weeks into quarantine. Something felt fishy about that, but I thought I must be envious. My thoughts seemed trapped at a distance, beyond a flatness to which I was dedicated: a Royal Emptiness I dared not defy.

Then I read Andre Green's chapter on "the dead mother," and the swirling elements fell into a choreography. The dead mother, owing to a loss (as of a child or parent) changes suddenly into one "who remains alive but who is, so to speak, psychically dead in the eyes of the young child in her care" (Green, 1983, p. 142). We are experiencing something like this, I thought. Like defenseless infants, unprepared and at the mercy of nature's swift and dark pivot, we've had no choice: we live in uncharted territory, marked by iterations of emptiness. The virus seems alive, ravaging populations, but is inanimate; COVID-19 is alive in its deadness, deadening in its vitality. Even Zoom promises connection that flattens on a screen. I had perhaps identified with our dead-mother-world, as Green's analysands had with their "dead mothers," desperate to remain attached even if to psychic absence itself.

By the growing light of this idea, response patterns among patients and communities were also illuminated: many recalled Green's "dead mother 
complex"! Previously a hodgepodge, the responses now appeared like two manifestations of this complex: deadness and manic aliveness. I will elaborate on these as expressed in communities and an individual patient, discuss hazards of such responses, and explore possibilities for healing.

\section{Psychological Prelude: Facing the Unfathomable/Shock}

In the initial weeks, we must have been in shock. We braced ourselves for the worst (whatever that is for each of us), hoping to bridge a short-term crisis. As days passed, we couldn't discern if the worst would happen, was happening, or had happened. The crisis was both explicit (sirens, masks, video screens unveiling our home lives) and invisible behind manifold forbidden chambers (ambulances, hospitals, morgues, masked faces). Nothing was mournable, even as myriad essential components of life as we knew it-our quotidian; immeasurable personal connection; painstakingly constructed modes of earning a living-disappeared. As weeks unfolded into months, shock gave way to other reactions: versions of fight (conflict) and flight (activity), which together I am calling "manic aliveness," as well as freeze (deadness).

\section{Communities: Manic Aliveness}

The emergence of manic aliveness in those first weeks, lines up with Green's (1983) description of the child after his mother has turned cold; having "attempted in vain to repair the mother... [he] fought against anxiety by various active methods, amongst which agitation, insomnia and nocturnal terrors are indications" (p. 150). Indeed, increased sleep disturbance was widely reported (Brooks et al., 2020; Gualano, et al., 2020). Now, fear and anger also rose as palpable twin forces on professional listservs and social media. Commotion flourished in these now hyperinvested "chambers," which became saturated with haste to virtue-signal and a profound pull to moralize. Combining the lenses of Green and Klein helps make sense of this pull: under the threat of a blank mourning-a "hole," like Green's (1983, p. 155), at once empty and containing hate, rage and confusion (pp. 152-153) - we may react from a paranoid schizoid position (Klein, 1946), secure in alliances formed via scapegoating.

Despite this reactive, unstable atmosphere, it was on the heels of these responses that psychological formulations on the pandemic next multiplied. Some were very keen, but with the paradox of trauma being unknowable as it unfolds, the seeming rush to define what was happening suggested to me a defensive productivity. Patients and friends unknowingly supported my 
hypothesis in making declarations of their "obligation" to "make the most of this time." Some were able to articulate what may have undergirded this: panic and despair about unprecedented levels of uncertainty. And Green ultimately clarified for me that this flurry felt like his analysands" "highly productive intellectualization... [and] precocious idealized sublimations" (p. 153).

Importantly, the content of a given assessment at that stage may hold value-per Green (1983), "I see no reason... to contest their authenticitybut I think as an attempt to master the traumatic situation... [it] is doomed to fail" (p. 153). Further, as possible attempts to recapture a "lost breast," they struck me as the "creation of a patched breast, a piece of cognitive fabric... destined to mask the hole" (p. 152). Fast efforts to define the pandemic could have simplified and foreclosed its yet untold significance. "False breast(s)" (p. 160) will, by definition, leave us painfully dry. In zealously narrating (doing), we may prevent being with our less symbolizable experience and drawing from its richness. And, we risk never laying to rest the dead mother.

\section{A Patient: Deadness}

Jade is an aspiring singer-songwriter. When she first landed in my office she was "paying [her] dues" while seeking her "break": bartending to make ends meet while spending twice as many unpaid hours on her music. Her energy and motivation were sapped by a moderate depression, one that also sharpened a self-criticizing voice within her. Jade was concerned about stagnating, but hopeful about therapy. Indeed, Jade's progress writing songs seemed to respond to her increasing play with her mind's contents in sessions.

Within a month of quarantine-which Jade spent with her parents, as bars had closed-Jade's fluctuating struggle to write songs ground to a halt. She saw moral depravity in diverting energy to music "when the world is burning." As if oblivious that so much music is wrought from pain and activism, she complained that her work was divested of meaning. Her blatant oversight puzzled me. Her overall demoralization seemed (immediately) responsible, and it frustrated me. Finally recognizing her likeness to Green's analysands', who exhibit sudden "impotence... to make the most of [their] talents" (p. 148), my frustration softened; my curiosity grew.

Overlooking more of the obvious, Jade lost willingness to follow her trains of thought in session, dismissing them as "not the right path" despite good understanding of analytic principles. Exploring the pattern, our discussions flowed more (and I momentarily felt hope), but they quickly 
became intellectual debates. I grew more demoralized, myself; intellectualization seemed to be the only mode Jade could tolerate. Discovering that this was prominent in Green's analysands-"intellectualization keeps one 'away from what [one] has learned' (and I think, could learn) 'of one's unconscious'" (p. 158)—was relieving. In resonating with my experience of Jade and her experiences, the model enlivened me in receiving her. It also seemed to hone my empathic accuracy; Jade increasingly responded to my reflections with feeling.

One day, Jade mentioned something, curiously for the first time: as a mixologist, it had become her thing to create a cocktail for each friend that expressed their personality. Some were "sweet with a touch of spice," some "velvety smooth," and others "tart and tangy, with a punch." Intrigued by this colorful description, I hoped the feeling signaled a renewal of play. But when I asked what kind of cocktail would represent her, she was stumped, finally settling on "just water."

Unlike other symbolic meanings for water like sustenance, birth, or purification, her conclusion struck me as indicating flavorless, or blankness; she agreed. Blankness as identity is core to dead mother complexes, reflecting the "negative identification... with the hole left" (p. 155). Her associations to others, meanwhile, resonate with Green's description of his analysands' pain, "colouring all the cathexes," while a "feeling of a captivity... dispossesses the ego of itself and alienates it to an unrepresentable figure" (p. 153).

Then came a session in which Jade seemed preoccupied with a certain childhood movie scene. Mixed in with family tapes she was digitizing, she found The NeverEnding Story (Petersen \& Eichinger, 1984). She vented hatred for this movie that apparently all of her childhood friends loved. "Why such vitriol?" I asked. "Because of that scene where the horse dies, don't you remember?" I did. It was heart-wrenching. The hero, Atreyu, yanks his beloved horse's bridle, urging the horse to escape quicksand. The horse's muzzle alone jolts forward while the horse sinks. Atreyu wails everdesperately, finally seeming to shatter. "You never actually see it die," Jade lamented, "so it's just stayed with me, perpetually, all this time." Having made the connection with Green for a while now, I was stunned. She went on: "it's interesting how the one who needs to fight most seems to be giving up." I heard myself asking, "Who is that?" She knowingly answered, "Yep, it's me." In identifying with both Atreyu and his horse and in being plagued by this scene "perpetually," Jade mirrored Green's complex in which one "becomes [her] own mother" and is "mortgaged" to her (p. 163). But in Jade's "yes" I heard sadness, in her passion, rage and despair. Something in her was waking up, and connecting with me, if timidly. 
Jade returned to Brooklyn as bars reopened, which meant renewing her lease. Recently, pending re-closures and the approaching winter, Jade has compared herself with friends who left the city "for sunnier pastures" and felt discouraged and "directionless." What has slowly grown, however, is Jade's interest in conveying nuanced qualities of her feelings, in such an intimate way that I sense her bringing me in. We agreed in a recent session that this was so. Then, she said, "Yeah... sometimes it's like there's a hole here. Like I could fall into it pretty soon... filled with more of this nothing." I asked, "Am I there with you? It almost feels like we're hanging out on the edge of it..." to which she replied, "yes, that is what it's like," not so flatly now.

\section{Why It Matters: Hazards}

Though they are attempts to escape trauma, manic aliveness and deadness keep us entombed in it. While they inherently employ denial and disguise, something in our felt experience betrays these maneuvers. I felt entombed in my early experience of the pandemic, with parts of me trapped beyond walls, and I knew something was awry. On the other side of manic aliveness and deadness in others, I felt myself walled off by them, hemmed out from their vulnerable selves.

Manic aliveness and deadness, at least as dead mother complex phenomena, are likely to entomb us because they are a kind of posttraumatic repetition compulsion (Freud, 1920; Green, 1997). We, "unconscious of this identification with the dead mother... [reunite] henceforth in recathecting the traces of the trauma" (Green, 1983; p. 151). Apprey's (2014) pluperfect errand elucidates how this family of repetition compulsions entraps. Without direct mention, the dead mother concept is prominent in Apprey's descriptions of inherited trauma, which he says, leave in the offspring "a compartment within the mental representation of the inside mother" (p. 16). Illustrating its effects via a film character, he quotes, "the hole I am about to tumble into... is that of her silence" (p. 19). Apprey's main argument, then, is highly applicable: this type of trauma involves a "toxic mandate," and the very effort to escape it activates and fulfills a deadly errand.

Manic aliveness and deadness also indicate collapsed thinking. A collapse of thinking occurs in all trauma, via collapse of time and spaceour usual guardrails for linear and logical thinking - and urgency to escape threats to our basic security. COVID-19 has wrought profound collapse and continues to do so: sirens signal collapse of bodies but also of institutions, governance, economy, and justice. Allured (2019) recently described 
"constricted self-states evoked by catastrophe" related to the preexisting socio-political and environmental contexts. Early in the pandemic, Dodds (2020) identified our likely "generalized psychosocial breakdown making it hard to think" under threat of the combined virus and "viral" dimensions like fascism. Such unfathomable collapse makes our reactivity in deadness and manic aliveness particularly perilous. Corrosion of unity via scapegoating, and separation in deadness, are just beginnings of the damage that is possible.

Finally, there is simultaneity. Pervasiveness means we are all affected, all of the time. We cannot step for a moment outside of it by narrating and formulating, or by any other method. We cannot know (if we ever did), amidst trauma unfolding, that we are "keeping one foot ashore" while only the patient regresses, relying on old measures of analytic imbalance. In my own "deadness," taking a curious and tolerant/permissive stance towards it may have helped me be with my patients' experiences more safely, as well as receive Green meaningfully and discover the resonance his ideas had for me. Time will reveal more, and I hope to remain curious and open. Staying alert to countertransference has always been crucial, but the task is indisputably changed. It demands we ask ourselves, on repeat, "What (and how) is the interaction of I and my patient's pandemic experience?"

\section{Healing: Towards Relinquishing the Dead Mother}

Amidst constriction and terror, we grasp manically at control or seek refuge in the blankness. How do we heal? Dodds (2020) declares, "out of crisis comes renewal," but it depends how it is sought. He suggests caution. Given the dead mother nature of this pandemic, I believe caution should include heeding Green's counsel to slow down and acknowledge that we must relinquish old notions of "normal":

The lesson of the dead mother is that she too must die one day so that another may be loved. But this death must be slow and gentle so that the memory of her love does not perish, but may nourish the love that she will generously offer to her who takes her place (Italics added; Green, 1983, p. 172).

If our thinking is collapsed much of the time, let us attend to what expands capacity, not just for "thinking" per se, but for dreaming and playing as well. Between here (trauma, collapsed thinking, manic aliveness, and deadness) and where we want to go (I dream of greater calm, security, productivity, justice, unity, and love), I imagine a middle ground that might allow for the "slow and gentle" process Green references. Winnicott's (1953) transitional 
space and processes resonate with me as such. We don't rush from subjective to objective in our early development, but make use of an intermediate area, replete with imaginary friends and worlds that span and defy these categories. We accept this as necessary in children (p. 91) but often forget it may be so for adults, especially in trauma and transition.

These ideas are now woven into our understanding of "creative repetition." Freud initially proposed that productive functions of some forms of repetition may be harnessed in play and creativity (Freud, 1920). Loewald coined the term creative repetition and emphasized its use in the transference-countertransference to "lay to rest" our ghosts (Loewald, 1960). And Reis (2019) expanded on how to do this, such that repetition in a potentially closed loop may transform into a more open-ended process that vitalizes patient and analyst, and in so doing brings forth new possibilities. The simultaneity of the pandemic calls for liberal application of these ideas and their crucial ingredients. These include practices of patience and willingness - to tolerate, receive, join, forgive, and improvise.

In this spirit, a slow drawing and re-drawing of our experiences, in openended exploration rather than a rush to define, might allow the dust to settle so richer fantasies of a new normal may take shape. Some hypocrisy here, and the meta-aspects of this essay, are not lost on me. My hypothesis about the pandemic as a kind of dead mother is a formulation, but I hope none too absolute. More optimistically, it is documentation simply in being an exploration available to dialogue and evolutions of understanding. More important than my hypothesis may be my attempt to understand. I hope it is a useful relic for our future: "documentation" of what it was like to try to understand our experience as it unfolded.

\section{TRAPPED: FINDING WAYS IN AND OUT OF MENTAL ANGUISH IN THE PANDEMIC}

\section{Nancy Freeman-Carroll}

Contagion. Quarantine. March 2020. The pandemic changes the boundaries of our daily lives, and even those lucky enough to live in adequate spaces feel impinged on, limited, thrown together in quarters closer than we usually keep. In the first lock-down, schools close and we are inside our homes except for limited forays to buy groceries or walk the dog. I escape the city with my family to a small beach home we recently inherited. I continue to work, finding a corner where the screen can face a blank wall to disguise where I am and the relief, and guilt, I feel in leaving town. Despite my departure, we are all caught in the collective trauma of fear of the spread 
of the COVID-19 virus; we are trapped by how this present crisis evokes our past terrors.

For Dee, a married woman in her 70s, her psychological space is further narrowed as her husband's mental status also shifts, his grasp of everyday reality changes, gradually, but irrevocably, with each week. Following the lockdown in mid-March, her life would become an effort to preserve her view of herself, of her husband and their romance in the face of his evolving senility, echoing our larger effort to sustain ourselves in the face of the natural calamity of viral contagion. Dee and her husband had begun to manage shifts in the equilibrium of their relationship, changes provoked by his vulnerabilities (becoming more easily short-tempered, diminished memory) which invariably touched her susceptibility to feeling ignored and alone. She felt persecuted by his behavior and guilty for harboring persecuting feelings. They epitomized what Andrew Balfour (2015), in a sensitive article "Growing Old Together in Mind and Body" has described as a "claustrophobic quality of being trapped or in flight from pressing realties of age and what it augurs" (p. 55). The entrance of the pandemic into this scene weighted Dee's fears of her husband's, and potentially her own, fragmenting self. Balfour (2015) references Joyce McDougall (1985) in his discussion of the pressures of aging on the self-concept; however, this captures the tension and anxiety raised for my patient and her husband, for all of us, in light of the threat of catching COVID-19:

How do we manage to bind the wounds to our narcissistic integrity caused by external realities such as the fact of aging and finally the inevitability of death? ....Most of us manage to make unstable adjustments to these realities but there is little doubt that...in our unconscious fantasies we are all omnipotent...externally young and immortal (McDougall, quoted in Balflour, p. 58).

Even under ordinary circumstances, Dee struggles to fall asleep. As her insomnia worsened in March and April, she turned to meditation tapes and found they evoked memories of her mother reading aloud from Christian Science pamphlets. I knew her mother had adopted Christian Science; she escaped the competition within her immediate family, and the broader Jewish community, with an attachment to the world of Christian Science, where in Dee's words, "the present matters less than the promised afterlife." For Dee's mother, Christian Science was a refuge from the race to achieve middle class status, a suburban home, a well-married daughter. Unfortunately, her sense that life was a disappointment was still felt by her only child, Dee, who imagined that she was the cause of her mother's unhappiness. 
The tone of the meditation tapes, and the Christian Science Doctrine remembered as, "don't worry about today's disappointments, you will get more in the hereafter," all remind Dee that she has always been looking for solutions-meaning or value-to reassure herself. She has absorbed her mother's belief that there must be something better, or closer to what is needed in life; she grasped that her mother was not a true believer in a future reward, but held onto her Christian Science beliefs because they took the sting out of ordinary reality. In today's world, Dee is also in need of something to soothe her from the loss of ordinary life to quarantine, and her expectations of her loving husband.

Dee reflects on her husband's memory loss and its emotional consequences: increasingly he questions something she remembers, and he argues with her, grilling her for details, unwilling to acknowledge he is wrong. These disagreements can fill her with a sense of being erased, of not mattering. She is caught in an après-coup that evokes the pain of a childhood in the shadow of her mother's unhappiness, marginalized by her parents' romance, worried over, but not given space-her bed literally squeezed into the immaculate living room of their one-bedroom home. She feels guilty because she is filled with anger, in addition to panic. Following her memories of the Christian Science pamphlets, she remembers past moments of personal anguish, and feels overwhelmed at her repeated sense of vulnerability. Has she ever found relief? Is there relief NOW? The sense of finding something familiar in these memories, of re-finding, now, the old helplessness hangs in the air between us.

How can we manage the sense of vulnerability brought on by the need to quarantine in our homes, the required remote sessions, the lack of control that is embedded in each new reality "both frighteningly alien and strangely familiar, when we are reminded of a repressed and forgotten aspect of ourselves" (Dodds, 2011, p. 197). Dee complains, worries, envies others' success, competes with close friends, with me, and her argumentative warmth and neediness bring us closer together as we negotiate life in the first weeks of isolation. Dee repeats her sense that she felt very vulnerable as a child, with each lapse in her husband's memory she feels "he is forgetting not only $x$, but also me." She is full of rage: confounding her memories of her mother with her present-day frustrations with her husband, with me, with the pandemic and its restrictions.

I met Dee years ago, as she faced the imminent death of a long-term beloved analyst. We have negotiated that loss, and the periodic bouts of insecurity related to her creative work and the shape of her life. We have found common ground in our shared interests and pleasure in each other's company. We were beginning to speak of concluding our work when her husband showed signs of cognitive decline, raising her anxiety, and 
expressed dissatisfaction. Not long after, the COVID-19 pandemic changed our relationship, and all others. We pass thoughts back and forth, volleying her husband's future and the helplessness that can accompany our current circumstances. We wonder together which domain is less under Dee's control? We have parallel experiences related to her anger: she feels guilty when she lashes out at her husband, but nonetheless is very hurt when he cannot validate her point of view. I register and control my alarm at her potential to erase their many satisfying years of marriage in fantasies of escaping him. Après-coup pulls me towards minimizing the virus and our need for careful behavior-I also need to temper my reactions to her, her description of her physical need for care, my admiration of her sensuality, and her determination to maintain closeness with her husband.

Dee married in her 40s, and describes a solid relationship with her husband, highlighting their continued physical romance, despite the passage of time. She also notes their long-standing differences: he tends to be compulsive and controlling, whereas she is creative and less orderly. $\mathrm{He}$ has become less able to manage details of their life that have been his domain. When he can't remember something, he can slip into asking detailed questions that hide his confusion, but also seem uncannily like his familiar obsessional habits. He is becoming difficult to live with, inspiring Dee with fantasies of escape, despite her consistent, protective care of him. Her guilt and rage threaten to spoil everything-infecting her view of everything around her-like the virus, which seems to control everyone, seeping into everything. She asks: "How can I possibly be here? Why did I pick him? Why is life better for others?" We both hear the echo of her mother's discontent, the après-coup, re-shaping memories into the present panic.

Dee sees her mother in her husband; she laughs as she tells me that her husband sees himself in the TV character Monk (Breckman \& Hoberman, 2002-2009), a police detective with OCD, and watching the show together in recent weeks gives them rare moments of relaxation. In a recent session, she describes a close friend with whom she shares Sunday walks, despite her friend's reluctance to use a mask. She remembers another old friend who had an obit in the paper that day, a black man, and remembers an intimate moment with her mother from the 1970s. Her mother had called as she was hosting this man for dinner and they colluded to keep the friendship hidden from her father. Her thoughts revolve around control and breaking away - she was transgressive from her parent's perspective and independent in her own eyes. She gets her friend's wish to defy social norms (go out without a mask) and admits to her ambivalent feelings and reactions: her fear, a wish to criticize, and exert control. 
Dee has a sense of humor and laughs at the ridiculous all or nothing sense the Christian Science teachings evoke in her. She is not one to ignore the natural reality-she wears a mask-still the thought that all of today's problems, including the pandemic, might someday not matter at all is comforting to her. The après-coup shapes her wish for safety, and she imagines there will be a day when her husband will also be gone, and she will be "free" from the present frustrations. Several weeks go by before she has the strength to admit, "I don't find this a good fantasy any longer."

Her husband sleeps for hours every day. She is disconcerted by his behavior, but she is especially reassured when there is physical affection between them. He suggested recently that they try to have sex-the following day - they have negotiated playfully for years with dates planned around his use of Viagra, but recently rarely attempted, but the next morning, when she asked him if he had taken his pill, he responded abruptly that he didn't know what she was talking about. This last mistake, of multiple moments when he has forgotten what he planned to do, leaves her feeling intense anger. Her wail, "How did I get here? (stuck inside with someone who can't remember me)" echoes our broader despair at the pandemic that keeps us all at a distance from things we want to do: How did we not notice what was happening? Not plan for this eventuality? Not have a way out? It is hard to call out who or what is responsible, perhaps as Dodds (2019) suggests,

[L]ife in the Anthropocene era involves denial of both outer reality and inner feelings of guilt.... We seek refuge in the lie and fantasy to reassure ourselves against a threatening reality, or we seek a reassurance in "external" reality to avoid the guilt connected with fantasy realized (p. 199).

Dee is among the patients I have known the longest and she is among the most senior. We are bonded in our efforts to make sense of life on the screen in Zoom sessions, measuring our tolerance for the present limitations in our daily lives. I try to tolerate the intense anger she expresses towards her husband, gently probing for the panic about his health, translating her frustration with him into her frustration with the world. How will she manage his decline now that it is inescapable? We commiserate about the layers of irritation in her life, of the multiple ways in which she--at home and in public - cannot know what the future will bring. For the moment, she is trapped: by quarantine, COVID-19, and her husband's cognitive decline. As her husband withdraws, we recognize the losses involved for both of them. Over the summer, she participates in a group for caregivers of individuals with dementia and he, too, joins a group for individuals coping with cognitive decline. They find humor in some of his memory loss and 
evidence of her own. She returns to some creative work outside their home and notices she feels less trapped inside herself, but there is tension in her views of the landscape outside her window. Before the pandemic she documented a sense of openness that she no longer feels: the atmosphere has changed.

\section{WORKING THROUGH IN THE PROFOUND UNKNOWN OF COVID-19}

\section{Naomi Cutner}

We have always had the unknown to contend with, but we have mostly been able to push it aside and go about our lives as though we knew what was coming-except when we were attacked by a foreign power or experienced a frightening storm. But now the new and in many ways still unknown coronavirus is so enormous and confounding and has caused so much death and loss that we have less ability to deny our ignorance. Working with patients in this climate is challenging in a new way, as we are all scrambling to put our lives together and are profoundly uncertain about when or how we will emerge from this disturbing reality.

It is a unique situation when therapist and patient are coping with the same circumstance, especially something of the magnitude of COVID-19. To some degree we share what we are going through, which causes a shift in the relationship's asymmetry. We become more the same. In other ways, however, we have differing responses to the situation, to the extent that we are different in our capacity to live with the unknown and tolerate adversity. My training has taught me to withstand and contain what my patients present and provides me with resources that support me in my work.

I have been working with Kathy since mid March of last year, which was shortly after the shutdown. We are the same age and both Jewish. She chose to talk on the phone, so we have never met or seen each other. It is unusual and strange to begin working this way. Therapists sense into aspects of a patient's experience by reading facial expressions and body language. Even if people are lying on a couch, their physicality, how they hold themselves, is a form of communication.

As I have gotten to know Kathy though, I began to understand why she might have chosen to talk on the phone for our sessions. She told me she had a painful childhood, was emotionally neglected by both parents, got no affection, and that the family was destroyed due to her father's gambling. Through her work in a long a previous analysis she came to understand the degree of emotional neglect she experienced. Eventually Kathy also appreciated that her father was capable of kindness, unlike her mother, 
and saw her promise. She had a close relationship with an aunt (by marriage), who introduced her to a wider world. I believe that her experiences of being unseen and dismissed as a child, in addition to her discomfort with her weight, make it difficult for her to be seen by a stranger who might also neglect or hurt her.

In Kathy's view, her intellect allowed her to survive. She excelled in school, got multiple degrees and became was a successful businesswoman, developed a rewarding second career and then retired. In the volume, Edward Corrigan and Pearl-Ellen Gordon (1995a, b) edited and contributed to on precocity and pathological self-sufficiency, they write that "certain patients, in order to manage overwhelming anxieties, seem to have turned, omnipotently, to their mind-establishing it as their most reliable object." For Corrigan and Gordon "it is useful to think of ...patients who exploit their intelligence in the service of defense, as exhibiting precocious ego development" (1995a, pp. 3-4).

Kathy made a good amount of money, bought a fancy home, and then lost a large sum when she sold it. She has written an unpublished memoir and is also writing a mystery. After her retirement, she spent time with friends, taught seniors to use cell phones, started writing and joined her writing group, and was active in her synagogue. Since the lockdown she joins Zoom meetings with her synagogue and her writing group and talks a little with friends and a niece. She is otherwise quite isolated. She barely goes out but will on occasion cross the street to sit in her car, where she feels safest and most comfortable. Kathy longs for connection but reports feeling inept at engaging with others on a personal level. She could function well in the working world but getting close to people is unnerving. She is clearly reluctant to create the opportunity for me to see her.

When we began, Kathy often complained about how hard it is to have to do so much for herself, especially cooking and cleaning. She usually has help but curtailed it for now. She can't carry much from the market so now has deliveries. She had a knee replacement in January and was doing physical therapy, but her therapist left town as COVID-19 spread and she felt she was falling behind in her recovery. She wanted to see her cardiologist but was told there was no need to meet. She was especially angry that she could not get medical care: another rejection. Kathy's distress about her physical well-being was magnified by the fact that in her 40 's she developed a benign brain tumor that caused deafness in one ear, was removed, grew back and had to be removed again. There were further complications, including a stroke, but she made a remarkable recovery.

I told Kathy about a physical therapy practice where she could be seen but she did not follow up. On the day after our conversation about her anger, I understood that such practical suggestions would not help. What 
she needed was to be angry, because without her outrage she would feel terribly alone and neglected. The pandemic left her fending for herself, with few outlets, and seemingly landed her back in her bleak childhood, with people she could not rely on. Her professional ability to see a problem and fix it could not serve her during this time. Here the conditions created by the pandemic ignited an experience of profound helplessness. The usual supports-helpers, social interaction, engaging activities-have been knocked down, and someone like Kathy, with a painfully insecure attachment to her caregivers, would be subject to heightened anxiety and a feeling of tremendous isolation.

A number of weeks went by before Kathy mentioned her ex, Gail. They were together for 15 years; the relationship ended about six years ago. Gail has been involved with someone else for a while. Kathy told me how she took care of Gail, much more than the other way around. In some ways Gail did not make room for Kathy, but for Kathy it felt good to be chosen, to belong. They were somewhat friendly now, and Kathy felt an urgent need to stay connected to Gail. She knew it wasn't good for her to pursue the friendship, because she wanted more than she could have. And she knew that even if they were together, Gail would not provide her with the emotional closeness she craved.

During one session, Kathy talked about her obsessive preoccupation with and offers to help Gail. As she described the problems in the relationship once again, I nodded off. I was tired, but there was also the impersonal way she was communicating, as though I was not yet a person to her. After all, we had never seen each other. I heard her ask "are you still there?" I said I was and apologized. She said you must have gotten distracted and I said that I had. She went on about her ex, and when I asked a question, she repeated with irritation that I was distracted and said she didn't feel connected to me. It was the end of the hour. I apologized again and we said goodbye.

I was concerned with how I had handled this moment and saw how her experience of feeling neglected and wounded had played out with me. I thought further about what may have contributed to my falling asleep. I remember feeling disturbed by her attentions to her ex and thinking that she was setting herself up for hurt, and that I could not stop her. But perhaps it was my own sense of helplessness that put me to sleep. Like Kathy, I am single, and the pandemic has at times left me feeling painfully alone. It was likely that Kathy's intense need for a friendship with Gail, and the hurt that Gail is not there for her, triggered my feelings of vulnerability and loneliness and put me to sleep.

I thought I might inquire further about my failure during our next session, but when we spoke then she was full of news about having felt sick (it was 
not COVID-19) and the medical care she got, which clearly soothed her. She went on to say that she realized she had gotten too caught up in a fantasy about her ex and would limit her attempts to help her. I didn't inquire about our awkward moment, thinking I would listen for other signs of her feeling abandoned by me.

When I am in session with Kathy, I move from feeling critical of her frustrations with our current reality, perhaps to insulate myself from my own feelings of loss, to tuning into her pain and feelings of isolation. She talks about wanting community, and about her difficulty making personal connections. She longs to be in a smaller place, less dense, where she would find a gay community, with access to the outdoors, but has no idea where she would go. Lately she has been invited to some small outdoor gatherings, where people wear masks and sit apart. She reported enjoying herself at these events in spite of her worries that she would not be able to think of things to say. She has befriended a woman she met through her synagogue, met up with her a couple of times, and is tentatively interested in pursuing her. Though it might take her a while to realize that she is hurt or angry, she gets around to telling me when I have done or said something that upset her. During one session I found myself wondering if her negative thoughts about her body were valid, and with my eating disorder work in mind, unthinkingly asked her for her height and weight. She told me, but the following week let me know how distressed she was that I had asked. She felt scrutinized in a way that was hurtful. I had unwittingly tapped again into her painful vulnerability.

Four months into our work together there was a shift in Kathy's mood. She decided to head for a nearby town for a week where she once had a home. She took a hotel room and made plans to visit with old friends, outside and at a distance. We spoke during that week and she sounded relaxed and content. She had seen friends on consecutive days and was pleased with her time away. I saw how vital it was for her to reconnect with friends.

When she got back to town, she was disappointed to discover that a synagogue group she joined via Zoom was changing in a way that she didn't like. But she moved on. She decided to allow her housekeeper to come, and she developed an idea about going back to work in the town she had visited. This excited her as she imagined spending time there. Her fantasy quickly evaporated due to a number of barriers. But she was not surprised and thought she might find a way to work in the city. She had a difficult night, which happens periodically, but she had plans to have dinner with a friend the following night. She completed a task in her apartment that she wasn't sure she could handle, and she was pleased with her accomplishment. She said that she had learned from the pandemic just how much she 
missed connecting with others and that she yearned for a close quality friend, someone who could be her person. She also reached out to her synagogue friend and had a good talk with her. This friend has a community of other friends and may not always be around, but it seems that Kathy is gradually coming to grips with her cruel disappointments and is enjoying her small victories in the time of COVID-19. I feel an ease growing between us, and that I am becoming a person she can trust. Just recently she referred to the possibility of a video session. She moved on quickly to another issue, but it was a small opening to the possibility of being fully seen.

\section{AFTERWORD}

\section{Adrienne Harris}

The planning and writing and work, now manifest in these papers, took place as the meaning and implications of this pandemic deepened and opened into more and more frightening realities. A new reality of environmental and medical challenge and danger opened into an endless vista of economic, social and political tumult. Dodds (2011) calls this complex context the three ecologies: mental, social and environmental. In this context, as you can absorb from these clinical stories, our work, the ongoing living world of the consulting room, the therapeutic dyad, however transformed through frames and modes of work never quite imagined, continues, a source of nourishment to analyst and patient. Clinical work, at the moment, in this altered context brings many challenges, but also, as these accounts attest, our clinical work is precious.

Altered in formats and frames, work with patients is also familiar, identity sustaining, and-it is important to acknowledge-maintains a sturdy continuity of economic support and stability. This, complexly, can yield both guilt and relief. A known, inhabited, and inhabitable world continues even as everything is changed and changing. This work, we must also notice, is occurring in situations that are not stable, not resolved, filled with uncertainties that are political, social, economic and medical. Again, we see the presence of the three ecologies.

We first collected this jointly written and assembled essay nine months into interlocking crises; a scant month before a terrifying election; and in contexts where the future and current status of many structures we depend on, had became radically unsettled. There is a radical uncertainty in the fate and presence and status of educational sites, commerce, entertainment, social settings where people gather, sites of support, work, exploration and 
care. Some urban streets turned into places full of despair and danger and, at the same time, the presence of others can be calming and organizing.

The analysts writing their clinical stories here present not only accounts of their work with people at different developmental levels, they also present complex ideas about the frame and its transformations, expectable and novel. Frame changes may offer a potential for something subversive. It is a practice, in a sense established by the State, by medical and political authority. It brings the analytic couple into different arrangements of intimacy and estrangement. Home is closer. Identification and difference can be accentuated. We see sometimes unexpectedly for both parties, something of the toxic splitting lessens and some potential for noting humanity in self and others grows. These are the bright moments in these stories.

But no clinical moments is very far from the fear of the unknown, the unknowable, the deep presence of helplessness, the many consequences of après-coup. I am going to end on a personal note. I think like many colleagues I am in discussion with, there is the mix of guilt and fear; of the relief at places of shelter and peaceful circumstance, and disruption of law and democracy that arrives through the airways and print media.

I have been anchored by the stable presence of family as well as the stability and vitality of work. My grandson begins preparing for school in the new normal: remotely, which, indeed, seems just the right term for what is happening, interwoven with pods-social experiences crafted to allow some form of social engagement and contact. His reading for English, he tells me is Bryan Stevenson's (2014) Just Mercy and F. Scott Fitzgerald's (1925) The Great Gatsby. The adults around him struggle to imagine this combination: the carceral society and the imagined freedom of money and status. I am trying to imagine a not infrequent reverie-_"what Bob would think" - my late husband, Robert Sklar, a cultural historian who wrote about Fitzgerald. There are many moments, I suspect, for all of us, when we think about family and loved ones we have lost and feel the relief that they have been spared this moment, even as this experience is the outcome of many forces for which we, collectively, are all responsible.

Now I think of what he would have said about reading Gatsby. Reading some of his work I see a surprising link. Fitzgerald's novel, written in the traumatic aftermath of the first world war and is about the longing to preserve culture, refinement, and grace and the tragedy in which criminality and wealth misused, wreaks havoc on the natural and social world. The longings and antagonisms between America's East and West feels prescient in this moment, along with the murderous dangers to democracy. 
I end with a quote from The Great Gatsby. It is the last line, actually and the quote that I put on Bob's tombstone: "So we beat on, boats against the current, borne back ceaselessly, into the past" (Fitzgerald, 1925, p. 182).

\section{NOTES}

1. Adrienne Harris, Ph.D., is Faculty and Supervisor at New York University Postdoctoral Program in Psychotherapy and Psychoanalysis. She is on the faculty and is a supervisor at the Psychoanalytic Institute of Northern California. She is an Editor at Psychoanalytic Dialogues, and Studies In Gender and Sexuality. In 2009, she, Lewis Aron, and Jeremy Safran established the Sándor Ferenczi Center at the New School University. Currently, she directs the center with Miriam Steele. She, Lew Aron, Eyal Rozmarin and Steven Kuchuck co-edit the Book Series Relational Perspectives in Psychoanalysis which has published over 100 volumes. She is a Coordinating Editor of the IPA online ejournal psychoanalysis.today and serves on the editorial boards of Psychoanalytic Dialogues and Studies in Gender and Sexuality. Her book Rocking the Ship of State was published in 2008 and she is finishing a new book Gender Fixed and Fluid.

2. Veronica Csillag, LCSW, is past co-director, a faculty member, and a training and supervising analyst at the Manhattan Institute for Psychoanalysis, faculty, National Institute for the Psychotherapies and Associate Editor, Psychoanalytic Dialogues. She is a former faculty member at the NYU School of Social Work and The Jewish Board. She is the author of several psychoanalytic papers, published in various journals, including the American Journal of Psychoanalysis, Psychoanalytic Dialogues and the Psychoanalytic Quarterly. She is in private practice in New York City.

3. Naomi Cutner, LCSW, is a graduate and former faculty of the NYU School of Social Work, and a graduate of the Manhattan Institute for Psychoanalysis, where she is a supervisor and the director of the institute's clinic.

4. Nancy Freeman-Carroll, PsyD., is a supervising analyst and faculty member at The William Alanson White Institute; former faculty of MIP, ICP, NIP; the Associate Editor of Contemporary Psychoanalysis and Journal of Infant, Child and Adolescent Psychotherapy, an active member of the Mental Health Professionals Group of The American Society of Reproductive Medicine; she has published and presented on support for clinicians and parents negotiating disclosure of assisted reproduction. She is in private practice in New York City.

5. Sarah Jo Mayson, PhD, is a clinical psychologist in private practice in New York City, clinical supervisor at Pace University, and psychoanalytic candidate at the New York University Postdoctoral Program in Psychotherapy and Psychoanalysis.

6. Marilina Rufino, Ph.D. received her doctoral degree in Clinical Psychology from The New School for Social Research in 2013. She also received her licensure in Psychology from the University of Buenos Aires in 1997. She currently is a staff volunteer supervisor at Lenox Hill Northwell, and psychoanalytic candidate, New York University Postdoctoral Program in Psychotherapy and Psychoanalysis. 


\section{REFERENCES}

Allured, E. (2019). The tragedy of the earth's commons. In P. Montagna \& A. Harris (Eds.), Psychoanalysis, law, and society (pp. 41-55). New York: Routledge.

Apprey, M. (2014). A pluperfect errand: A turbulent return to beginnings in the transgenerational transmission of destructive aggression. Free Associations, 15(2), 16-29.

Balfour, A. (2015). Growing old together in mind and body. Fort Da, 21(2), 53-76.

Bion, W. R. (1957). Differentiation of the psychotic from the non-psychotic personalities. International Journal of Psycho-Analysis, 38, 266-275.

Bion, W. R. (1962). The psycho-analytic study of thinking. International Journal of Psycho-Analysis, 43, 306-310.

Breckman, A. (Creator) \& Hoberman, D. (Producer). (2002-2009). Monk [Television Series.] Mandeville Film: Touchstone. NBC Universal Network. USA.

Brooks, S. K., Webster, R. K., Smith, L. E., Woodland, L., Wessely, S., Greenberg, N., \& Rubin, G. J. (2020). The psychological impact of quarantine and how to reduce it: Rapid review of the evidence. Lancet, 395(10227), 912-920.

Corrigan, E. G., \& Gordon, P. E. (1995a). The mind as an object. In E. G. Corrigan \& P. E. Gordon (Eds.), The mind object: Precocity and pathology of self-sufficiency (pp. 1-22). Northvale, NJ: Jason Aronson Inc.

Corrigan, E. G., \& Gordon, P. E. (1995b). "Understanding too much" The treatment of a precocious young boy. In E. G. Corrigan \& P. E. Gordon (Eds.), The mind object: Precocity and pathology of self-sufficiency (pp. 55-82). Northvale, NJ: Jason Aronson Inc.

Dodds, J. (2011). Psychoanalysis and ecology at the edge of chaos: Complexity theory, Deleuze/Guattari and psychoanalysis for a climate in crisis. London: Routledge.

Dodds, J. (2019). Otto Fenichel and ecopsychoanalysis in the anthropocene. Psychoanalytic Perspectives, 16(2), 195-207.

Dodds, J. (2020). Elemental catastrophe: Ecopsychoanalysis and the viral uncanny of COVID-19. Stillpoint Magazine, 004: Apocalypse. Retrieved from: https:// stillpointmag.org/issue/004-apocalypse/.

Faimberg, H. (2013). The "as-yet situation" in Winnicott's "fragment of an analysis": Your father "never did you the honor of".... yet. The Psychoanalytic Quarterly, 82(4), 849-875.

Fitzgerald, F. S. (1925). The great Gatsby. New York: Scribner \& Sons.

Freud, S. (1920). Beyond the pleasure principle. Standard Edition, Vol. 18. (pp. 1-64). London: Hogarth.

Green, A. (1983). The dead mother. In On private madness (pp. 142-173). Madison, CT: International Universities Press. 1986.

Green, A. (1997). The intuition of the negative in playing and reality. International Journal of Psycho-Analysis, 78, 1071-1084.

Gualano, M. R., Lo Moro, G., Voglino, G., Bert, F., \& Siliquini, R. (2020). Effects of Covid-19 lockdown on mental health and sleep disturbances in Italy. International Journal of Environmental Research and Public Health, 17(13), 4779.

Guattari, F. (1989). The three ecologies. London and New Brunswick, NJ: Athlone Press. 2000.

Harris, A. (2020). Working in the shadow of COVID-19. Psychoanalytic Psychology, 38(2), 99-100. 
Herzog, A. (2020, May 20). How a game with my daughter helped us cope with quarantine and the past. The New York Times Magazine. Retrieved from: https:// www.nytimes.com/interactive/2020/05/20/magazine/covid-quarantine-child. html.

Klein, M. (1946). Notes on some schizoid mechanisms. The International Journal of Psycho-Analysis, 27, 99-110.

Laplanche, J. (1997). The theory of seduction and the problem of the other. International Journal of Psychoanalysis, 78, 653-666.

Laplanche, J. (1999). Essays on otherness. London: Routledge.

Laplanche, J. (2015). The temptation of biology: Freud's theories of sexuality. New York: The Unconscious in Translation.

Loewald, H. W. (1960). On the therapeutic action of psycho-analysis. The International Journal of Psycho-Analysis, 41, 16-33.

McDougall, J. (1985). Theaters of the mind: Illusion and truth on the psychoanalytic stage. London: Free Associations Books. 1986. [Originally published in French as Théâtre du Je. Paris: Editions Gallimard. 1982.]

Nancy, J. L. (2020). A much too human virus. In F. Castrillón,F. \& T. Marchevsky (2021). (Eds). Coronavirus, Psychoanalysis, and Philosophy Conversations on Pandemics, Politics and Society (pp. 63-65) London: Routledge. Also in the European Journal of Psychoanalysis. Retrieved from: https://www.journalpsychoanalysis.eu/a-much-human-virus/

Ogden, T. H. (2016). Destruction reconceived: On Winnicott's 'The use of an object and relating through identifications'. The International Journal of PsychoAnalysis, 97, 1243-1262.

Ogden, T. H. (2019). Ontologycal psychoanalysis or "What do you want to be when you grow up?" Psychoanalytic Quarterly, 88(4), 661-684.

Petersen, W. (Writer \& Director) \& Eichinger, B. (Producer) (1984). The NeverEnding Story. [Motion Picture]. Bavaria Film: Munich, West Germany.

Reis, B. E. (2019). Creative repetition and intersubjectivity: Contemporary Freudian explorations of trauma, memory, and clinical process. New York: Routledge.

Rosenfeld, H. (1971). A clinical approach to the psychoanalytic theory of the life and death instincts: An investigation into the aggressive aspects of narcissism. The International Journal of Psycho-Analysis, 52(2), 169-178.

Seligman, S. (2014). Paying attention and feeling puzzled: The analytic mindset as an agent of therapeutic change. Psychoanalytic. Dialogues, 24, 648-662.

Stevenson, B. (2014). Just mercy. A story of justice and redemption. New York: Spiegel \& Grau.

Sullivan, H. S. (1940). Conceptions of modern psychiatry. New York, NY: William Alanson White Psychiatric Foundation. 1947.

Winnicott, D. W. (1953). Transitional objects and transitional phenomena-A study of the first not-me possession. The International Journal of Psycho-Analysis, 34(2), 89-97.

Winnicott, D. W. (1959). The fate of the transitional object. In C. Winnicott, R. Shepherd, \& M. Davis (Eds.), Psychoanalytic explorations (pp. 53-58). Cambridge, MA: Harvard University Press.

Winnicott, D. W. (1963). Dependence in infant care, child care, and in the psychoanalytic setting. International Journal of Psycho-Analysis, 44, 339-344.

Winnicott, D. W. (1969). The use of an object. International Journal of PsychoAnalysis, 50, 711-716. 
Winnicott, D. W. (1974). Fear of breakdown. International Review of PsychoAnalysis, 1, 103-107.

Publisher's Note Springer Nature remains neutral with regard to jurisdictional claims in published maps and institutional affiliations. 